\title{
Bisphenol-A and Risk of Obesity Among A Sample of Egyptian Children: Role of Adiponectin as Biomarker of Exposure
}

\author{
Hend M. Abo El-Atta ${ }^{1}$, Adel M. El-Mansoury ${ }^{1}$, Amany K. El-Hawary ${ }^{2}$, Muhammad E.M. \\ Abdel-Naby ${ }^{1}$, Manar A. Helmy ${ }^{1}$
}

\begin{tabular}{|c|c|}
\hline & ABSTRACT \\
\hline $\begin{array}{l}\text { KEYWORDS } \\
\text { Bisphenol-A, } \\
\text { Adiponectin, } \\
\text { Childhood obesity, } \\
\text { BMI, } \\
\text { HPLC. }\end{array}$ & 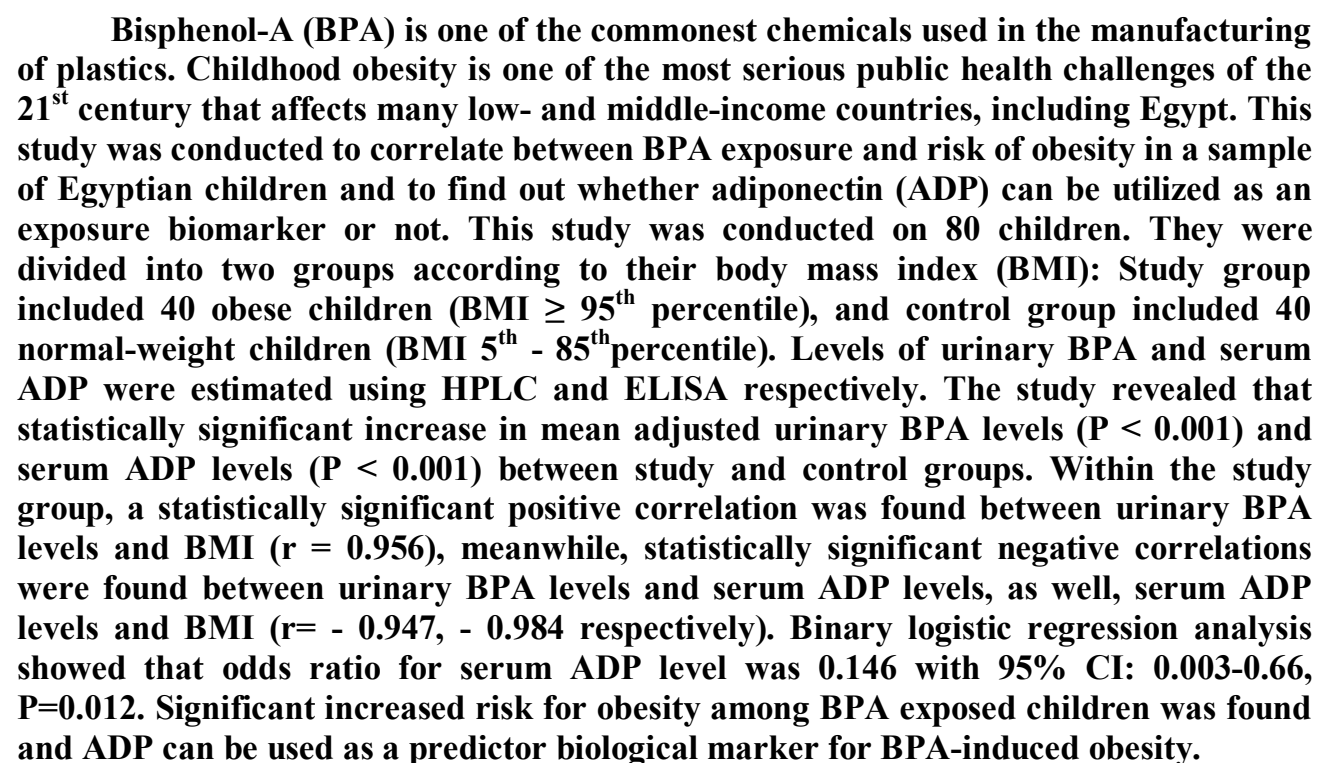 \\
\hline
\end{tabular}

\section{Introduction}

Bisphenol-A (BPA) is one of the commonest synthetic chemicals worldwide that is predominantly used in the manufacturing of polymers such as polycarbonate plastics and epoxy resins (Vom Saal et al., 2012). Besides, BPA is now well known as one of the endocrine disrupting chemicals that have the affinity to bind different hormonal receptors

\footnotetext{
${ }^{(1)}$ Forensic Medicine and Clinical Toxicology Department, Mansoura Faculty of Medicine-Egypt .

(2) Pediatrics Department, Mansoura Children Hospital, - Egypt.
}

and either inhibit or enhance hormonal actions causing dysfunction to the endocrine and neuro-endocrine systems, and interfering with normal hormonal regulation (Anglea et al., 2013).

Worldwide, childhood obesity is one of the most serious public health challenges of the $21^{\text {st }}$ century that steadily affects many low- and middle-income countries (Sibai et al., 2010). Children may be more susceptible to BPA exposure than adults as they still have immature organs, relatively low body weights and are going through a rapid physical development, thus, it could be a potential major public health concern, even with low levels of 
repeated exposure, in relation to the epidemic of childhood obesity (Rubin, 2011). Therefore, it is intriguing to hypothesize that exposure to BPA may have a role in weight gain and the development of obesity in Egyptian children.

Adiponectin is an insulin-sensitizing protein secreted from adipose tissue, and has been shown to improve glucose tolerance and insulin resistance in humans (Devasia et al., 2017). Many studies showed that metabolic syndrome, insulin resistance and obesity were associated with lower adiponectin (Pervanidou et al., 2013; Wilton et al., 2017). Menale et al. (2016) have declared an inverse association between adiponectin and BPA urinary levels independently in obese children; they explained that exposure to BPA leads to down-regulation of adiponectin expression.

This study aimed to correlate between bisphenol-A exposure and risk of obesity in a sample of Egyptian children, and to find out the role of adiponectin as a biomarker in bisphenol-A-induced childhood obesity.

\section{Subjects and Methods:}

\section{Subjects:}

A case-control study was conducted on 80 children 2-18 year-old of both sexes; recruited from Pediatric Endocrinology \& Diabetes Unit, Mansoura University Children Hospital (MUCH), Egypt; during their primary visits. An approval from Mansoura University Institutional Research Board was taken and informed consents were obtained from children's mothers.

Anthropometric measurement (weight, height) and BMI were calculated to all the studied subjects according to Wang et al. (2014) and then they were divided into two groups. The first group "study group": 40 obese children (BMI $\geq 95^{\text {th }}$ percentile). The second group "control group": 40 normal-weight children (BMI $5^{\text {th }}-85^{\text {th }}$ percentile). Exclusion criteria: children with hepatic, renal, endocrine or genetic disorders, those with history of intrauterine growth retardation, or corticosteroid therapy or born to diabetic mothers.

\section{Chemicals \& Kits:}

HPLC chemicals: bisphenol-A (analytical standard $\geq 99.9 \%$ ), bisphenol-BP (BPBP, analytical standard $\geq 98 \%$ ), B-Glucuronidase enzyme (Type HP-2, from Helix Promatia, aqueous solution, activity $\geq 100,000$ units $/ \mathrm{ml}$ ), acetonitrile, ethyl acetate, hydrochloric acid, sodium acetate buffer solution, potassium phosphate monobasic; were purchased from Sigma Aldrich Co., Egypt. ELISA kit Human adiponectin was purchased from SRB/Shanghai Sunred Biotechnology Comp., Ltd., Catalogue No. 201-12-1551.

\section{Methods}

Socio-demographic data including age, sex, residence and sources of exposure were obtained from all children's mothers.

From each child: $5 \mathrm{ml}$ urine was collected and stored at $-20{ }^{\circ} \mathrm{C}$ until analysis. In order to minimize external contamination with BPA during urine sampling and storage, the technicians were instructed to avoid contact of urine with plastic products during sample collection using glass centrifuge tubes (Wang et al., 2012). As well, $5 \mathrm{ml}$ blood was collected into a glass centrifuge tube, left for serum coagulation at room temperature for $10-20$ minutes, and then centrifuged for $15 \mathrm{~min}$ at the speed of 3500 r.p.m., and then the supernatant layer was aspirated. Finally serum samples were stored at $-20{ }^{\circ} \mathrm{C}$ until analysis

\section{Estimation of bisphenol-A using HPLC:}

Extraction of BPA by enzymatic digestion was done through previously described method by Matsumoto et al. (2003). This was followed by estimating levels using reversed phase high performance liquid chromatography with florescence detector (Agilent technology 1260 series) at Forensic 
Medicine and Clinical Toxicology Department, Mansoura Faculty of Medicine, according to parameters mentioned in table (I). Calibration curve was performed by using five serial concentrations $(10,20,60,80$ and $100 \mathrm{ng} / \mathrm{ml})$.

After estimation of the total concentration of BPA (ng/ml) by the previously mentioned procedure, it was adjusted to urinary creatinine concentration $(\mathrm{mg} / \mathrm{dl})$ to correct the urine volume according to Wang et al. (2012).

\section{Estimation of adiponectin using ELISA:}

All blood samples were analyzed using ELISA-Reader Readwell Strip apparatus (Assay range: $02-60 \mathrm{mg} / \mathrm{L}$, according to manufacture manual) at Clinical Pathology Department, Mansoura Faculty of Medicine.

\section{Statistical Analysis}

The collected data were processed and analyzed using the computer program SPSS (Statistical Package for Social Sciences) version release 20.0. Qualitative data were described using number and percent and quantitative data were described using median (minimum and maximum), mean and standard deviation. Student-t test and pearson correlation: for parametric quantitative variables. Mann Whitney test: for nonparametric quantitative variables. Binary logistic regression: for predictors detection. pvalue is significant if $<5 \%$

\section{Results}

Socio-demographic data:

Results and statistical analysis of sociodemographic data are shown in table (1).

Table (I): Chromatographic parameters used in the Agilent 1260 Infinity LC system.

\begin{tabular}{|c|c|c|}
\hline Parameters & \multicolumn{2}{|c|}{ Agilent 1260 Infinity LC system } \\
\hline TCC temperature: & \multicolumn{2}{|l|}{$40^{\circ} \mathrm{C}$. } \\
\hline FLD: & \multicolumn{2}{|l|}{ Ex: 230, Em: 316.} \\
\hline FLD acquisition rate, gain: & \multicolumn{2}{|l|}{$9.26 \mathrm{~Hz}, 15$} \\
\hline Mobile phase A: & \multicolumn{2}{|c|}{$10 \mathrm{mM}$ monobasic potassium phosphate in water. } \\
\hline Mobile phase B: & \multicolumn{2}{|l|}{$100 \%$ Acetonitrile. } \\
\hline \multirow{9}{*}{ Gradient: } & Time (min) & $\% \mathbf{B}$ \\
\hline & $\mathbf{0}$ & 5 \\
\hline & 2 & 5 \\
\hline & 2.1 & 35 \\
\hline & $\mathbf{1 2 . 5}$ & 35 \\
\hline & 12.6 & 70 \\
\hline & 17 & 70 \\
\hline & 18.1 & 5 \\
\hline & 23 & 5 \\
\hline Flow: & \multicolumn{2}{|l|}{$0.9 \mathrm{ml} / \mathrm{min}$} \\
\hline Injection volume: & \multicolumn{2}{|c|}{$\begin{array}{l}20 \mu \mathrm{L}, 5 \mathrm{sec} \text { needle wash at flush port for } 5 \mathrm{sec} \text {, using mobile } \\
\text { phase A. }\end{array}$} \\
\hline
\end{tabular}

FLD: The fluorescence detector in liquid chromatography 
The mean BMI was $33.32 \pm 5.31 \mathrm{~kg} / \mathrm{m}^{2}$ in the study group, compared to $17.78 \pm 1.11$ $\mathrm{kg} / \mathrm{m}^{2}$ in the control group. There was statistically significant increase regarding the mean anthropometric values between both groups ( $\mathrm{p}<0.001)$.

Table (1): Statistical analysis of socio-demographic data of the studied subjects (n:80).

\begin{tabular}{|c|c|c|c|}
\hline & $\begin{array}{c}\text { Study group } \\
(n=40)\end{array}$ & $\begin{array}{c}\text { Control group } \\
(n=40)\end{array}$ & Test of significance \\
\hline \multicolumn{4}{|l|}{ Age (years) } \\
\hline Mean \pm SD & $11.38 \pm 2.84$ & $12.33 \pm 2.03$ & $\begin{array}{l}t=1.72 \\
p=0.09\end{array}$ \\
\hline Range (min-max) & $5.0-15.0$ & $6.0-15.0$ & \\
\hline \multicolumn{4}{|l|}{ Sex } \\
\hline \multirow[b]{2}{*}{ Boys } & n (\%) & n (\%) & \multirow{3}{*}{$\begin{array}{l}\chi^{2}=1.53 \\
p=0.323\end{array}$} \\
\hline & $31(77.5)$ & $26(65.0)$ & \\
\hline Girls & $9(22.5)$ & $14(35.0)$ & \\
\hline \multicolumn{4}{|l|}{ Residence } \\
\hline \multirow[b]{2}{*}{ Rural } & n (\%) & n (\%) & \multirow{3}{*}{$\begin{array}{l}\chi^{2}=0.952 \\
p=0.329\end{array}$} \\
\hline & $30(75.0)$ & $26(65.0)$ & \\
\hline Urban & $10(25.0)$ & $14(35.0)$ & \\
\hline
\end{tabular}

n: number, $\chi^{2}$ : Chi square test, SD: standard deviation, t: Student-t test, min: minimum, max: maximum.

Figure (1) showed that all children in both groups $(n=80)$ were sharing the same dietary exposure sources, whether eating canned food or drinking water in plastic containers. As regard feeding during infancy (breast or plastic bottle feeding) or having dental filling, there were no statistically significant differences between the two groups $(\mathrm{p}=0.823$ and 0.592 respectively).

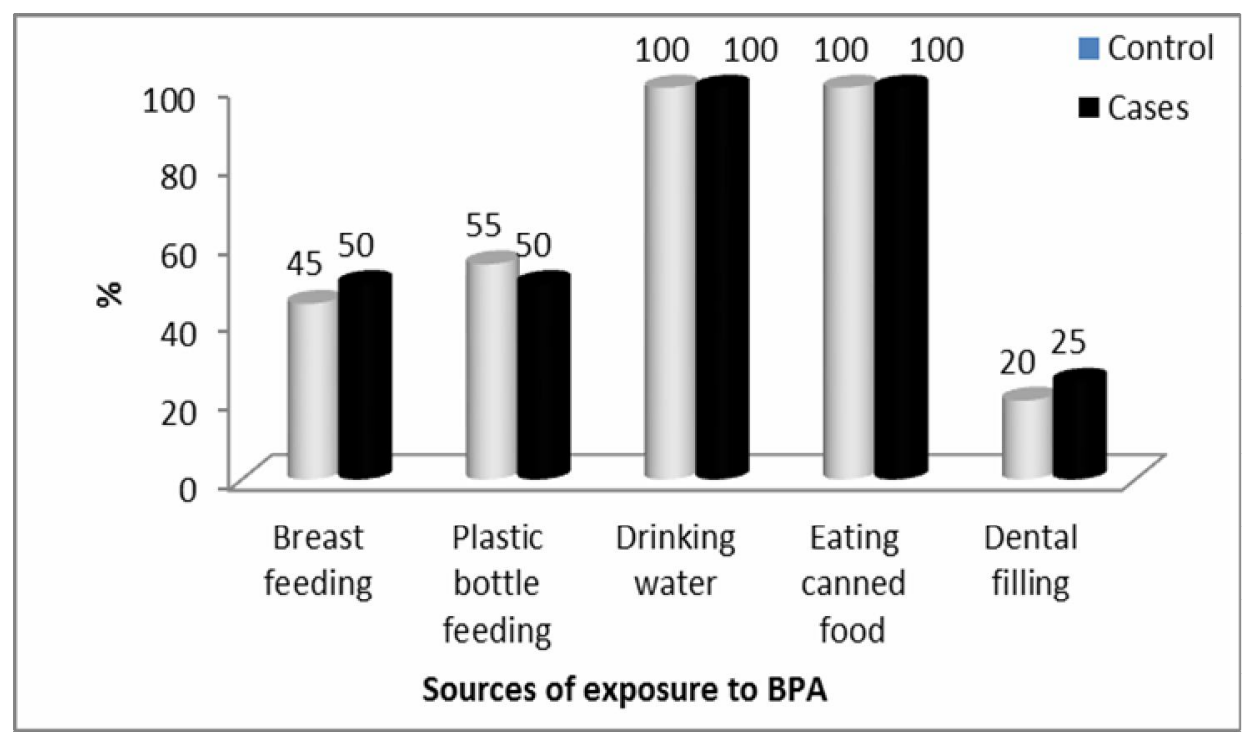

Fig. (1): Percentage of distribution of the studied groups according to their sources of exposure to bisphenol-A. 


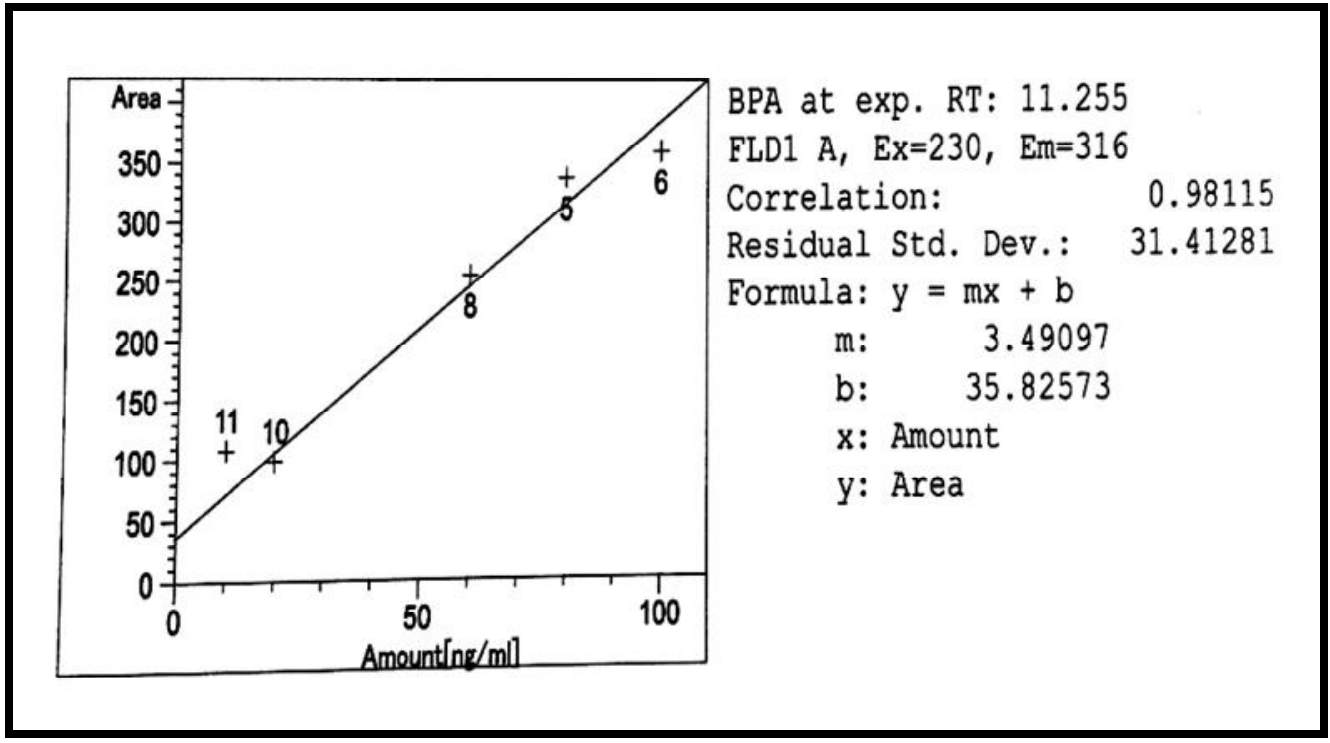

Fig. (2): Bisphenol-A standard calibration curve

\section{Chromatographic results}

By chromatographic analysis, the retention time of BPA standard was at 11.553 min. The curve was linear with correlation coefficient 0.98115 , as shown in figure (2). The limit of detection (LOD) of the used method was $1.7 \mathrm{ng} / \mathrm{ml}$. As regard the internal standard BPBP, its retention time was at $18.973 \mathrm{~min}$ (Figures 3 and 4).
The results of this study showed that serum ADP level can be used as a significant predictor for future obesity (odds ratio "OR": 0.146 with $95 \%$ confidence interval "CI": $0.003-0.66, p=0.012$ ). On the other hand, as regard urinary BPA level, the statistical results could not establish the possibility that BPA could be a predictor for childhood obesity.

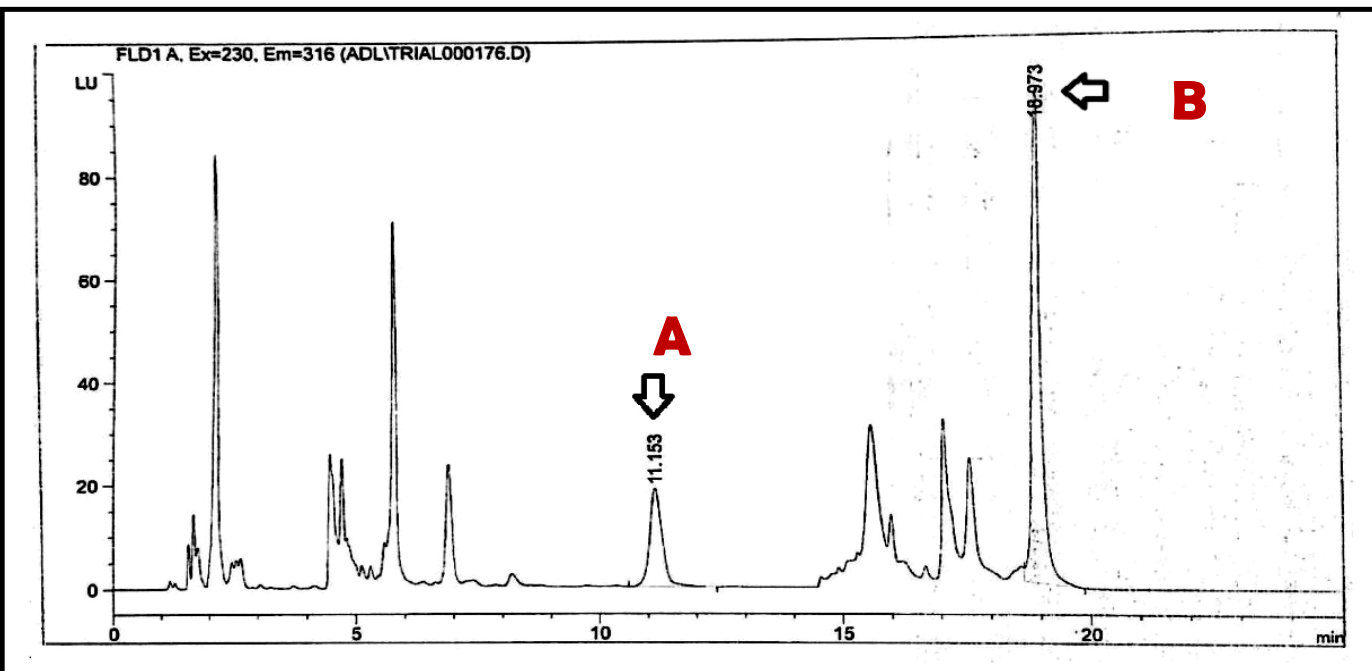

Fig. (3): HPLC chromatogram of BPA in one obese child showing: (A) detectable urinary bisphenol-A level peak at retention time 11.153 minute (> LOD*), (B) bisphenol-BP internal standard peak at retention time 18.973 minute. *Limit of detection (LOD): $1.7 \mathrm{ng} / \mathrm{ml}$. 


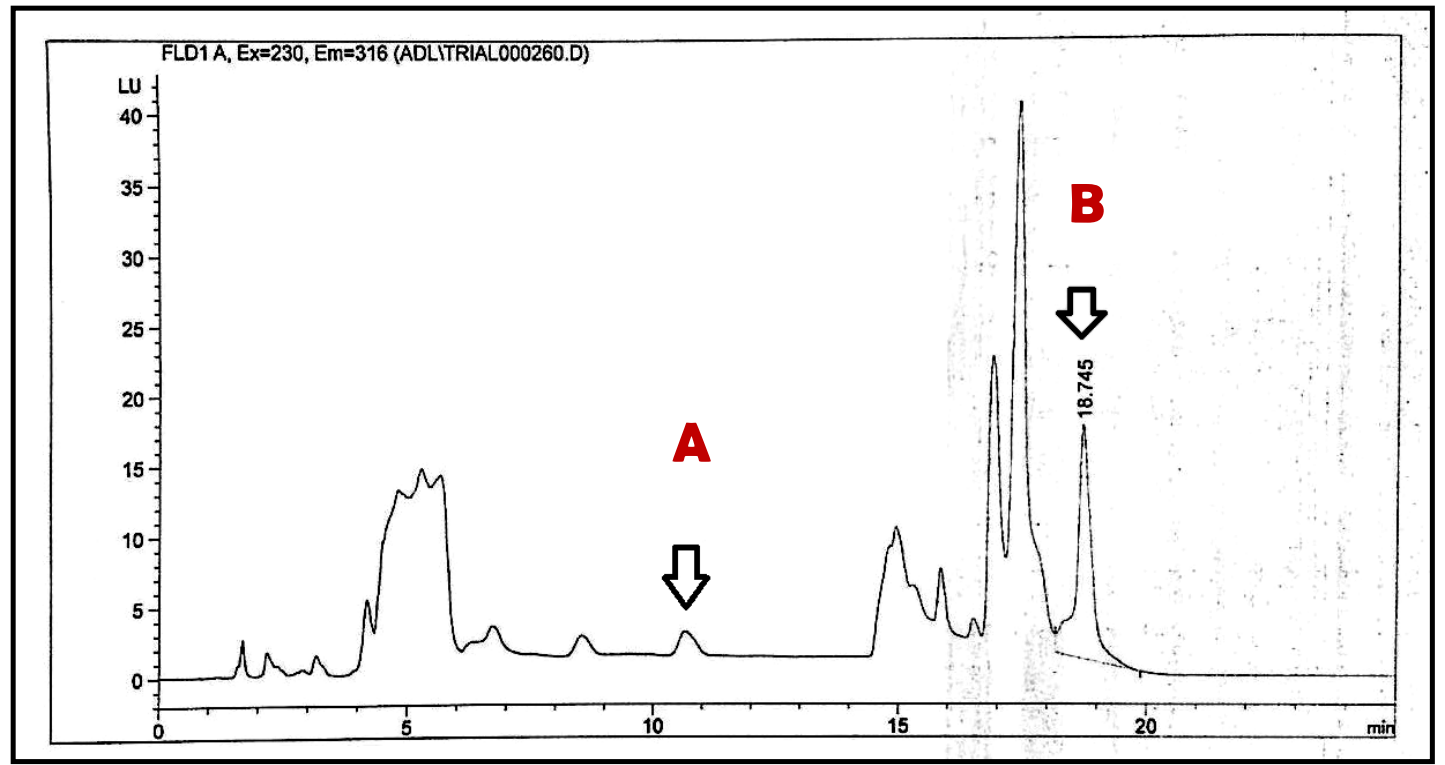

Fig.(4): HPLC chromatogram of BPA in one normal-weight child showing: (A) a non-detectable urinary bisphenol-A level peak $\left(<\right.$ LOD $\left.^{*}\right)$, (B) bisphenolBP internal standard peak at retention time 18.745 minute. ${ }^{*}$ Limit of detection (LOD): $1.7 \mathrm{ng} / \mathrm{ml}$.

Assay of urinary bisphenol-A and serum adiponectin levels in the studied children:

Statistical analysis of urinary bisphenol-A and serum adiponectin levels in the studied children is shown in table (2).

Table (2): Urinary bisphenol-A and serum adiponectin levels of the studied groups (n:80).

\begin{tabular}{|c|c|c|c|}
\hline & Study group $(n=40)$ & $\begin{array}{c}\text { Control group } \\
(n=40)\end{array}$ & Test of significance \\
\hline \multicolumn{4}{|c|}{ Urinary BPA level "volume-based/unadjusted" (ng/ml) } \\
\hline Median (min-max) & $\begin{array}{c}46.72 \\
(23.2-208.55)\end{array}$ & $\begin{array}{c}7.58 \\
(<\text { LOD }-31.3)\end{array}$ & $\begin{array}{c}\mathrm{z}=6.9 \\
\mathrm{p}<0.001 *\end{array}$ \\
\hline \multicolumn{4}{|c|}{ Urinary creatinine concentration $(\mathrm{mg} / \mathrm{dl})$} \\
\hline & $\begin{array}{c}40.75 \\
(28.16-63.23)\end{array}$ & $\begin{array}{c}54.32 \\
(10.2-157.08)\end{array}$ & $\begin{array}{c}\mathrm{z}=1.42 \\
\mathrm{p}=0.157\end{array}$ \\
\hline \multicolumn{4}{|c|}{ Urinary BPA level "creatinine-adjusted" ( $\mu$ g BPA/g creatinine) } \\
\hline Median (min-max) & $\begin{array}{c}121.89 \\
(39.22-586.97)\end{array}$ & $\begin{array}{c}14.92 \\
(<\mathrm{LOD}-34.94)\end{array}$ & $\begin{array}{c}\mathrm{z}=6.98 \\
\mathrm{p}<0.001 *\end{array}$ \\
\hline \multicolumn{4}{|l|}{ Serum ADP level (mg/L) } \\
\hline Median (min-max) & $\begin{array}{c}15.37 \\
6.42-21.02 \\
\end{array}$ & $\begin{array}{c}24.79 \\
19.53-126.75 \\
\end{array}$ & $\begin{array}{c}\mathrm{z}=7.61 \\
\mathrm{p}<0.001 *\end{array}$ \\
\hline
\end{tabular}

$\mathrm{z}$ : Mann Whitney test, LOD : limit of detection $(1.7 \mathrm{ng} / \mathrm{ml}),{ }^{*}$ Significant, BPA: bisphenol-A, ADP: adiponectin, ng: nanogram, $\mu \mathrm{g}$ : microgram, mg: milligram, $\mathrm{n}$ : number, min: minimum, max: maximum. 
Figure (5) shows a statistically significant and strong positive correlation between creatinine-adjusted urinary BPA levels and BMI within the study group $(\mathrm{p}<0.001)$, while in control group (Figure 6), a statistically significant and weak positive correlation among controls $(\mathrm{p}=0.037)$ can be noticed.

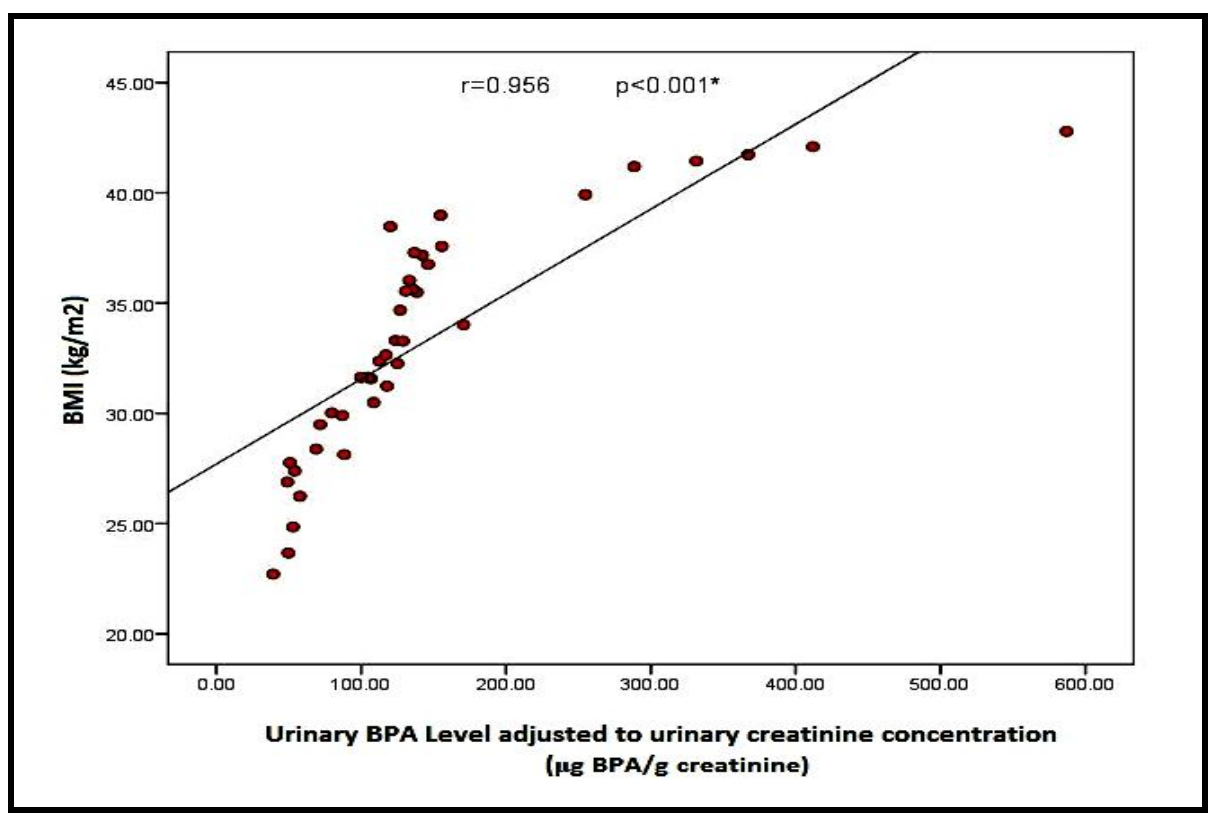

Fig.(5): A diagram illustrating the correlation between creatinineadjusted urinary bisphenol-A (BPA) levels and body mass index (BMI) in the study group $(n=40)$.

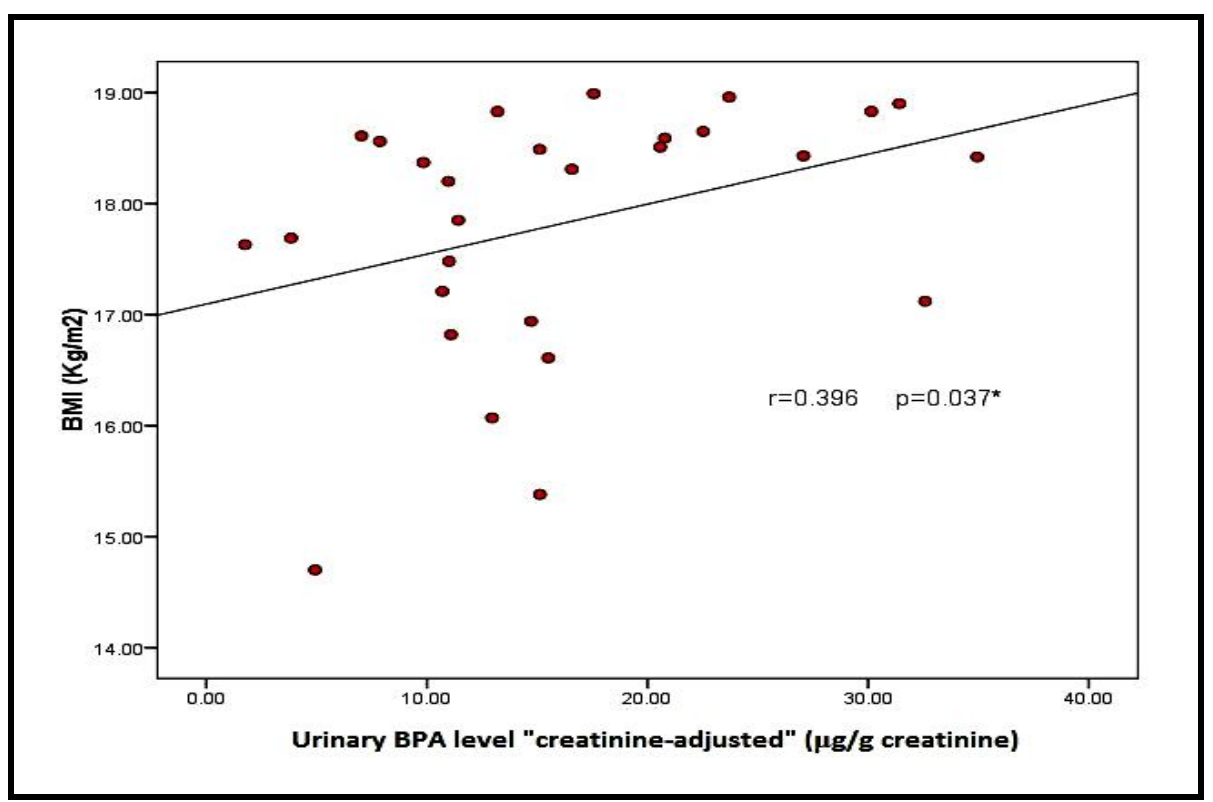

Fig. (6): A diagram illustrating the correlation between the creatinineadjusted urinary bisphenol-A (BPA) levels and body mass index (BMI) in the control group $(n=40)$. 
In figure (7), a statistically significant and strong negative correlation was detected between serum ADP levels and BMI in the study group $(\mathrm{p}<0.001)$, while in the control group (Figure 8), a statistically significant and weak negative correlation $(\mathrm{p}=0.017)$ was detected. In figure (9), a statistically significant and strong negative correlation between creatinine-adjusted urinary BPA levels and serum ADP levels in the study group $(\mathrm{p}<$ $0.001)$ was shown.



Fig. (7): A diagram illustrating the correlation between serum adiponectin (ADP) levels and body mass index (BMI) in the study group $(n=40)$.

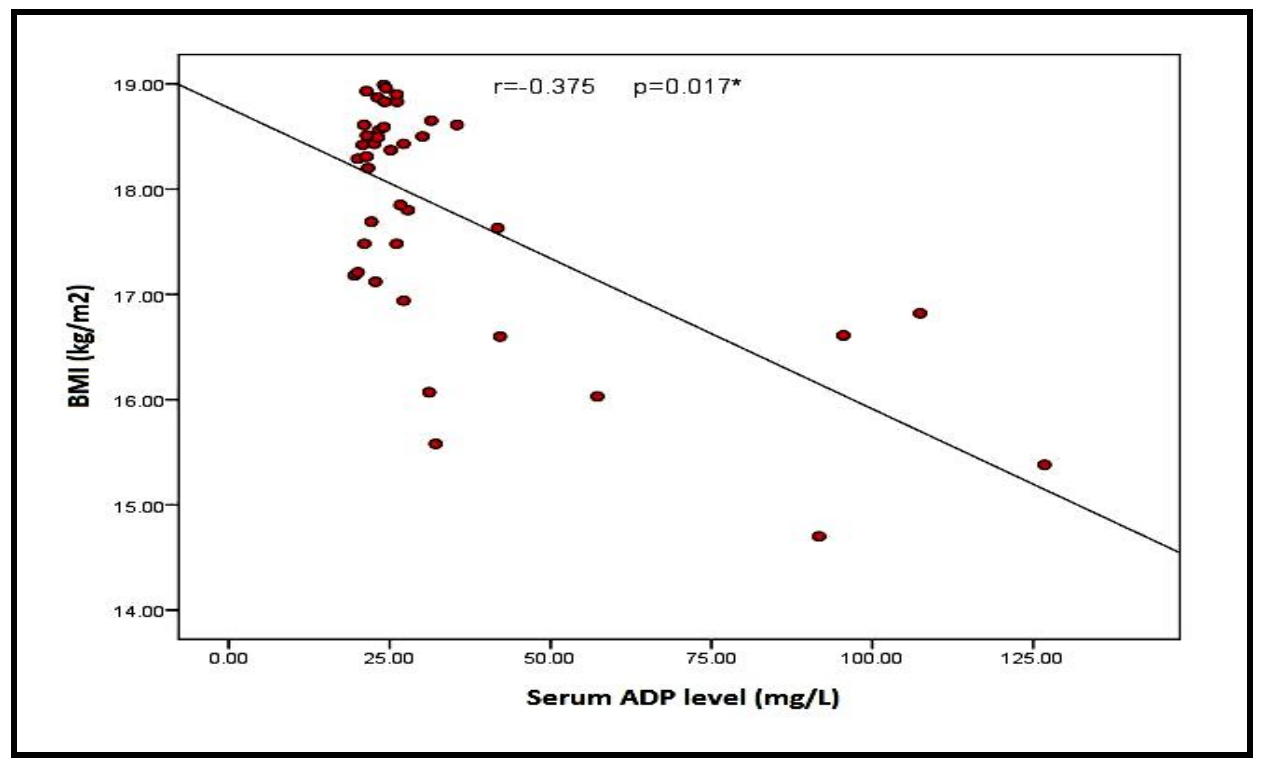

Fig. (8): A diagram illustrating the correlation between serum adiponectin (ADP) levels and body mass index (BMI) in the control group (n $=40)$. 


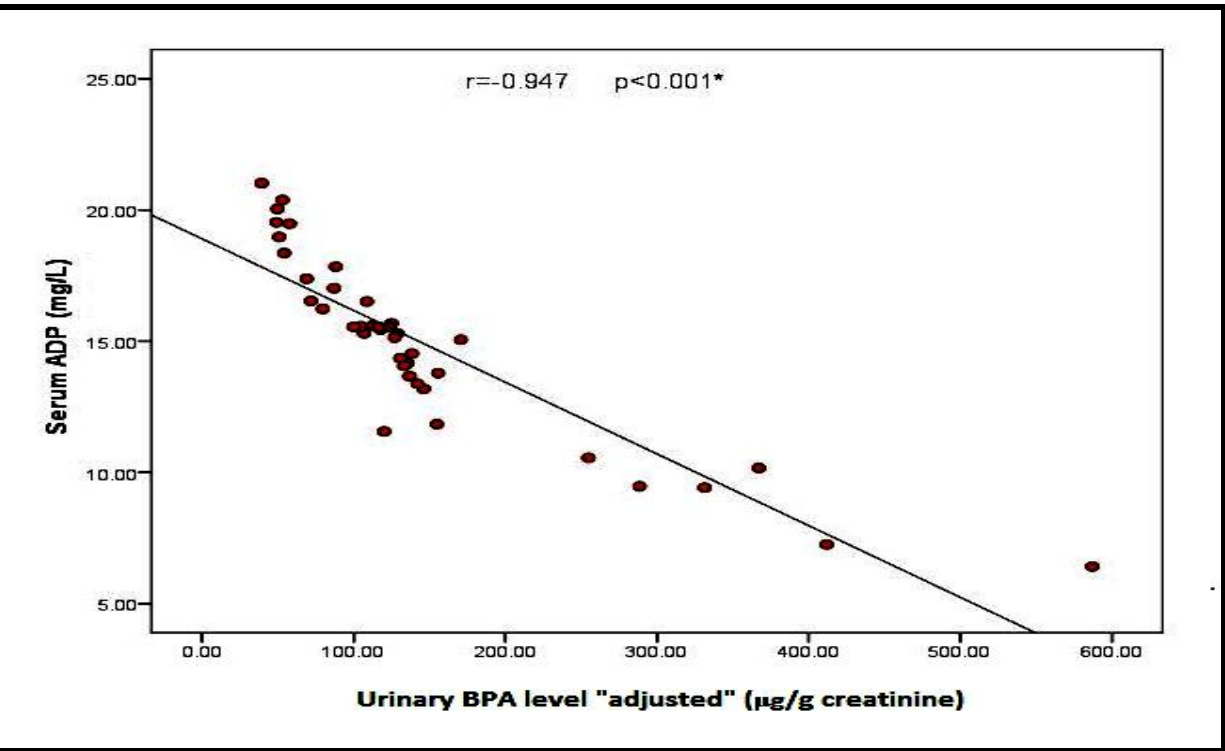

Fig. (9): A diagram illustrating the correlation between the creatinineadjusted urinary bisphenol-A (BPA) levels and serum adiponectin (ADP) levels in the study group $(n=40)$.

\section{Discussion}

Obesity is one of the most important health hazards of BPA that has been extensively studied by many researchers worldwide especially in children (Ehrlich et al., 2016; Hao et al., 2017). In this study, authors evaluated the correlation between BPA exposure and risk of obesity in Egyptian children through estimating the degree of association between urinary BPA concentrations and children's body mass index outcomes in our locality, and to find out whether adiponectin can be utilized as a biomarker in BPA-induced obesity or not.

The statistical results showed that nearly half of the studied children were breast-fed during infancy, while others were fed in plastic baby bottles; as well for older children, who used to eat canned food or drink water in plastic containers. Owing to its properties, BPA can be easily released from the polymer products in which it is present during heating or exposure to acidic or alkaline medium. As a result, free BPA is released and migrates into food, beverages and environment, enhanced by repeated washing with detergents, rubbing and sterilization of the BPA-containing products, besides, it is well absorbed orally (EFSA, 2006).

In the current study, a statistically significant increase in average values of creatinine-adjusted urinary BPA levels was detected between the studied groups. Similar results were reported in a cross-sectional study conducted by Wang et al. (2014), concerning exposure to BPA among school children aged 912 years old in Eastern China. They found that in the high-BMI children, the creatinine-adjusted urinary BPA levels were higher compared to normal-BMI group.

As well, a statistically significant and direct correlation between the creatinineadjusted urinary BPA levels and BMI was found in the study group. In agreement with these results, Wang et al. (2012) stated that daily BPA intake and urinary BPA concentration; were positively associated with BMI in Chinese school children. Similarly, Bhandari et al. (2013) 
and $\mathrm{Li}$ et al. (2013) observed that higher urinary BPA level was associated with overweight and obese children. However, studies conducted to prove such correlation are still sparse and inconsistent. Another study that was conducted by Li et al. (2017) on American children declared that higher BPA levels may be associated with elevated lean body mass in boys, while in girls, higher BPA levels may be associated with elevated fat mass.

This strong positive correlation between urinary BPA levels and BMI was explained by several in-vitro and in vivo studies: in invitro studies, it was accounted to its ability to trigger the differentiation of fibroblasts into adipocytes, as well, stimulating and accelerating the adipocyte conversion process, besides, enhancing basal and insulinstimulated glucose uptake and lipid accumulation in adipocytes (Angla et al., 2013). Confirming the results from in-vitro studies, the conducted in-vivo animal studies showed similar results to support the in-vitro studies' findings (Miyawaki et al., 2007; Patisaul and Bateman, 2008). That was explained with the ability of BPA to disrupt pancreatic $\beta$-cell function (Ropero et al., 2008 ) or interaction with ER- $\beta$ (Soriano et al., 2012); and subsequently results in insulin resistance. On the other hand, a study was conducted by Ishido et al. (2004), they reported either no significant or negative association between BPA and body weight.

Regarding serum ADP levels, a statistically significant reduction was found. Similarly, Diamond et al. (2004) found that mean serum ADP level in obese children was $9.1 \pm 3.7 \mathrm{mg} / \mathrm{L}$, compared to non-obese children (17.1 $\pm 12.3 \mathrm{mg} / \mathrm{L})$. As well, Panagopoulou et al. (2008) found that serum ADP levels were significantly lower in obese than non-obese children $(8.86 \pm 3.86$ versus $13.08 \pm 5.48 \mathrm{mg} / \mathrm{L}$ respectively).

In the current work, a statistically significant and negative correlation was found between the serum ADP levels and BMI in the obese children. This finding goes in accordance with Panagopoulou et al. (2008) who reported a significant negative correlation between decreasing serum ADP levels and increasing BMI among Greek children. Similar data were declared from previous similar studies conducted on people of different ethnic groups, such as Mexicans (Cruz et al., 2004); African Americans (Bush et al., 2005) and Asian (Tsou et al., 2004; Ogawa et al., 2005). On contrary, a German study that was conducted by Reinehr et al. (2004) found that ADP was negatively correlated only to percentage of body fat and no significant correlation between ADP and SDSBMI.

To the best of our knowledge, very limited previously reported studies assessing the correlation between urinary BPA levels and serum ADP levels among human (Rönn et al., 2014), they found that BPA is associated positively with the adiponectin release in human. However, several in-vitro studies have investigated the effect of BPA, as an environmental pollutant, on the kinetic pathways of the adipose tissue metabolic hormones, including ADP (Kidani et al., 2010; Menale et al., 2016). They declared negative correlation between exposure to BPA and expression of ADP. The present study is considered the first Egyptian study that investigated the correlation between BPA and ADP in obese children.

In the current study, serum ADP level was found to be a significant predictor for childhood obesity, meanwhile, BPA could not be established as a possible predictor, a result that differ from those of Bhandari et al. (2013) and Li et al. (2013), who reported a dose-response 
relationship between increasing urinary BPA concentrations and increased risk for future overweight and obesity. This observed contrast between the current results and those reported in the previously mentioned studies regarding BPA prediction for obesity can be explained by relatively much smaller section of population in this study that is considered a limitation to the results.

\section{Conclusion and recommendation}

The finding of this study proved that children with high BMI had significantly higher urinary BPA levels and lower serum ADP levels than those with normal BMI. This indicates significant associations between increasing urinary BPA levels, decreasing serum ADP levels and increasing BMI in children, with the possibility that ADP can be used as a biomarker for BPA-induced obesity.

Since children are more vulnerable to BPA exposure than adults, BPA may represent a novel, modifiable risk factor in relation to the epidemic of childhood obesity. Accordingly, further investigations are warranted regarding the biological effects of BPA on adipose tissue; as well as on the kinetics of different biomarkers that may have a role in induction of childhood obesity.

\section{Acknowledgment}

This research is a part of a competitipe research project. The authors acknowledge financial support from Mansoura University to this project.

\section{References:}

Anglea, BM.; Doa, RP.; Ponzia, D.; et al. (2013): "Metabolic disruption in male mice due to fetal exposure to low but not high doses of bisphenol A (BPA): Evidence for effects on body weight, food intake, adipocytes, leptin, adiponectin, insulin and glucose regulation". Reprod. Toxicol., 42: 256268. doi:10.1016/j.reprotox.2013.07.017.

Bhandari, R. Xiao, J. and Shankar, A. (2013): "Urinary bisphenol A and obesity in US children". American Journal of Epidemiology, 177(11): 1263-1270.

Bush, N.C.; Darnell, B.E.; Oster, R.A.; et al. (2005): "Adiponectin is lower among African Americans and is independently related to insulin sensitivity in children and adolescents". Diabetes, 54(9): 27722778.

Cruz, M.; García-Macedo, R.; GarcíaValerio, Y.; et al. (2004): "Low adiponectin levels predict type 2 diabetes in Mexican children". Diabetes Care, 27(6): 1451-1453.

Devasia, D.; Meiyappan, K.; Mohanraj, P.S.P.; et al. (2017): "Association between adiponectin and insulin resistance in diabetic urolithiasis". Oman Med. J., 32(2): 131-134.

Diamond, F.B.; Cuthbertson, D.; Hanna, S.; et al. (2004): "Correlates of adiponectin and the leptin/adiponectin ratio in obese and non-obese children". Journal of Pediatric Endocrinology and Metabolism, 17(8): 1069-1076.

Ehrlich, S.; Lambers, D.; Baccarelli, A.; et al. (2016): "Endocrine disruptors: A potential risk factor for gestational diabetes mellitus". Am. J. Perinatol., 33(13): 1313-1318. 
European Food Safety Authority "EFSA" (2006): "Opinion of the scientific panel on food additives, flavourings, processing aids and materials in contact with food on a request from the commission related to 2, 2-bis (4hydroxyphenyl) propane (bisphenol A)". The EFSA Journal, 428.

Hao, M.; Ding, L.; Xuan, L.; et al. (2017): "Urinary bisphenol A concentration and the risk of central obesity in Chinese adults: A prospective study". J. Diabetes, doi: 10.1111/17530407.12531.

Ishido, M.; Masuo, Y.; Kunimoto, M.; et al. (2004): "Bisphenol A causes hyperactivity in the rat concomitantly with impairment of tyrosine hydroxylase immunoreactivity". Journal of Neuroscience Research, 76(3): 423-433.

Kidani, T.; Kamei, S.; Miyawaki, J.; et al. (2010): "Bisphenol A down regulates Akt signaling and inhibits adiponectin production and secretion in 3T3-L1 adipocytes". Journal

Atherosclerosis

and

Thrombosis, 17(8): 834-843.

Li, D.K.; Miao, M.; Zhou, Z.; et al. (2013): "Urine bisphenol-A level in relation to obesity and overweight in school-age children". Public Library of Science One, 8(6): e65399.

Li, J.; Lai, H.; Chen, S.; et al. (2017): "Gender differences in the associations between urinary bisphenol A and body composition among American children: The National Health and Nutrition Examination Survey, 2003-2006". J. Epidemiol., 27(5): 228-234.
Matsumoto, A.; Kunugita, N.; Kitagawa, K.; et al. (2003): "Bisphenol A levels in human urine. Environ'. Health Perspectives, 111(1): 101.

Menale, C.; Grandone, A.; Nicolucci, C.; et al. (2016): "Bisphenol $\mathrm{A}$ is associated with insulin resistance and modulates adiponectin and resistin gene expression in obese children". Pediatric Obesity, World Obesity Federation, 1-8.

Miyawaki, J.; Sakayama, K.; Kato, H.; et al. (2007): "Perinatal and postnatal exposure to bisphenol A increases adipose tissue mass and serum cholesterol level in mice". Journal of Atherosclerosis and Thrombosis, 14(5): 245-252.

Ogawa, Y.; Kikuchi, T.; Nagasaki, K.; et al. (2005): "Usefulness of serum adiponectin level as a diagnostic marker of metabolic syndrome in obese Japanese children". Hypertension Research, 28(1): 51-57.

Panagopoulou, P.; Galli-Tsinopoulou, A.; Fleva, A.; et al. (2008): "Adiponectin and insulin resistance in childhood obesity". Journal of Pediatric Gastroenterology and Nutrition, 47(3): 356362.

Patisaul, H.B. and Bateman, H.L. (2008): "Neonatal exposure to endocrine active compounds or an ER $\beta$ agonist increases adult anxiety and aggression in gonadally intact male rats". Hormones and Behavior, 53(4): 580-588.

Pervanidou, P.; Charmandari, E. and Chrousos, G.P. (2013): "Endocrine aspects of childhood obesity". Current Pediatrics Reports, 1(2): 109-117.

Reinehr, T.; Roth, C.; Menke, T.; et al. (2004): "Adiponectin before and after weight loss in obese children". The 
Journal of Clinical Endocrinology and Metabolism, 89(8): 3790-3794.

Rönn, M.; Lind, L.; Örberg, J.; et al. (2014): "Bisphenol $\mathrm{A}$ is related to circulating levels of adiponectin, leptin and ghrelin, but not to fat mass or fat distribution in humans". Chemosphere, 112: 42-48. doi: 10.1016/j.

Ropero, A.B.; Alonso-Magdalena, P.; García-García, E.; et al. (2008): "Bisphenol-A disruption of the endocrine pancreas and blood glucose homeostasis". International Journal of Andrology, 31(2): 194-200.

Rubin, B.S. (2011): "Bisphenol A: an endocrine disruptor with widespread exposure and multiple effects". Journal of Steroid Biochemistry and Molecular Biology, 127(1-2): 27-34.

Sibai, M.A.; Nasreddine, L.; Mokdad, A. H.; et al. (2010): "Nutrition transition and cardiovascular disease risk factors in Middle East and North Africa countries: reviewing the evidence". Annals of Nutrition and Metabolism, 57(3-4): 193-203.

Soriano, S.; Alonso-Magdalena, P.; GarcíaArevalo, M.; et al. (2012): "Rapid insulinotropic action of low doses of
bisphenol-A on mouse and human islets of Langerhans: role of estrogen receptor beta". Public Library of Science One, 7(2): e31109.

Tsou, P.L.; Jiang, Y.D.; Chang, C.C.; et al. (2004): "Sex-related differences between adiponectin and insulin resistance in schoolchildren". Diabetes Care, 27(2): 308-313.

Vom Saal, F.S.; Nagel, S.C.; Coe, B.L.; et al. (2012): "The estrogenic endocrine disrupting chemical bisphenol A (BPA) and obesity". Molecular and Cellular Endocrinology, 354(1-2): 74-84.

Wang, B.; Wang, H.; Zhou, W.; et al. (2014): "Exposure to bisphenol A among school children in eastern China: a multicenter cross-sectional study". Journal of Exposure Science and Environmental Epidemiology, 24(6): 657-664.

Wang, H.X.; Zhou, Y.; Tang, C.X.; et al. (2012): "Association between bisphenol A exposure and body mass index in Chinese school children: a crosssectional study". Environmental Health, 11(1): 1-9.

Wilton, P.; Steidel, M.; Krczal, G.; et al. (2017): "Identification of highly specific scFvs against total adiponectin for diagnostic purposes". Biology, 6(2): 26. 


\title{
البيسفينول (أ) وخطر السمنة بين عينة من الأطفال الصصريين: دور الأديبونيكتين كعلامة بيولوجية للتعرض
}

\author{
أ. م.د. هند محمود أبو العطا ، أ.د. عادل المنصورى ، أ.د. أمانى الهوارى**

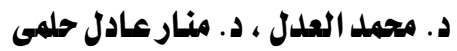 \\ من أقسام الطب الثرعى والسموم الإكلينيكية والأطفال * ـ كلية الطب ـ جامعة المنصورة
}

يعتبر البيسفينول (أ) أحد أكثر المواد الكيميائية شيو عا في تصنيع اللدائن. وتعد البدانة في مرحلـة الطفولة من أخطر تحديات الصحة العامـة في القرن الحـادي والعشرين والتي تؤثر على العديد مـن البلدان ذات الدخل المنخفض و المتوسط، بمـا في ذلك مصر . أجريت هذه الدر اسـة للربط بين التعرض الى البيسفينول (أ) وخطر لئر

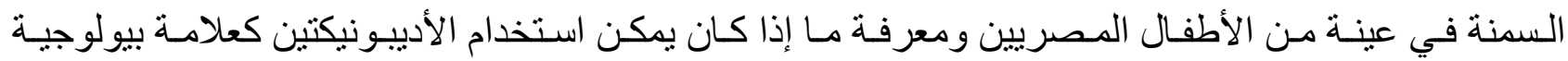
للتعرض أم لا. أجريت هذه الدر اسـة على ، ^ طفلا. وقد تم تقسيمهم إلى مجمو عتين وفقا لمؤشر كتلـة الجسم: مجمو عة الدر اسة ضمت ، مـ طفلا يعانون من السمنة المفرطة (مؤشر كتلة الجسم > 90)، و المجمو عة الضابطة

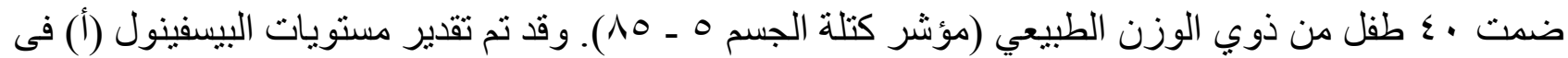

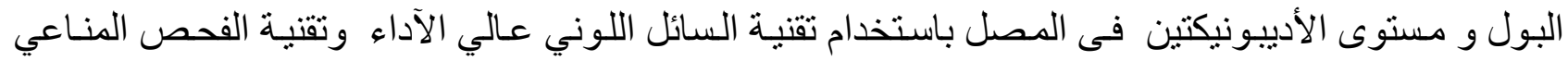

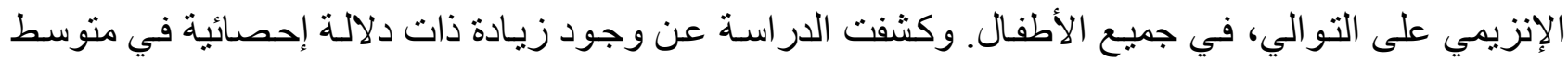




إحصائية بين مستو يات البيسفينول (أ) البولية ومؤشر ات كتلة الجسم (r = 0.956)، كما وجدت ارتباطات سلبية

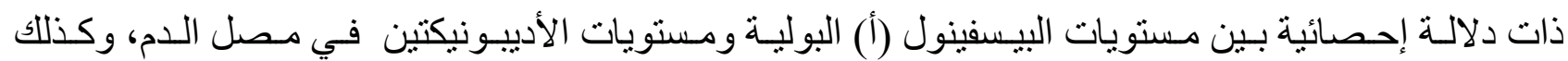
مستويات الأديبونيكتين في الدم ومؤشر كتلة الجسم 0.947 - r = r 0.984 - على التوالي). كما أظهر تحليل

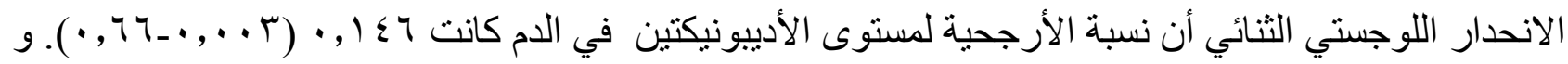
من هذه النتائج نستخلص حدوث زيادة كبيرة في خطر السمنة بين الأطفال المعرضين للبيسفينول (أ) ويمكن استخدام الأدييونيكتين كعلامة بيولوجية لتوقع البدانة الناجم عن البيسفينول (أ). 